\title{
The Effectiveness of Learning Method Towards Anti- Corruption Attitude at the Second Year (Group B) Kindergarten Students in Central Java
}

\author{
Desti Pujiati ${ }^{1}$, Myrnawati Crie Handini $^{2}$, Moch Asamawi ${ }^{3}$ \\ \{missdestyumpp@gmail.com ${ }^{1}$, myrnawati@unj.ac.id ${ }^{2}$, asmawi.moch@yahoo.id ${ }^{3}$ \} \\ Universitas Negeri Jakarta, Indonesia ${ }^{123}$
}

\begin{abstract}
This study aimed to determine the effect of learning methods on anti-corruption attitudes of kindergarten students in Central Java province. This study applies experimental research methods, with the sample of 44 students ( 22 students in the experimental class with the role-playing method and 22 students in the control class with the storytelling method) in Kindergartens in the Central Java. The results of the study show that: there is an effect of learning methods on anti-corruption attitudes. Students taught by the role-playing method have a better anti-corruption attitude than the students taught by the storytelling method. It can be concluded that the teachers' learning method can affect the anti-corruption attitude shown by the students in the learning process.
\end{abstract}

Keywords: learning method, role-playing, storytelling, kindergarten, anti-corruption attitude

\section{Introduction}

Realizing a clean and democratic government, the idea of anti-corruption is a very important theme to be developed in the era towards democracy in Indonesia. This is based on the reality of a culture of corruption that is plaguing government and society.

Based on the corruption ranking of several countries in Asia (PERC, Corruption in Asia, 2006), Indonesia had been deemed Asia's most corrupt country in 2006. In 2016 Indonesia was ranked fourth in the decline of corruption in the Asian country. However, this is still far from expectations; this has become very alarming and detrimental as the concern for many people. Corruption is considered a global problem. Based on KPK's data on the total handling of corruption cases from 2004-2016, there found 780 cases, investigation of 500 cases, prosecution of 408 cases, inkracht of 337 cases and execution of 357 cases.

Based on the Corruption Eradication Commission [KPK], the corruption case happened to the regional head in Indonesia, like Central Java, South Sulawesi, and North Sulawesi are found as the most corrupt regions in Indonesia. From the data supported by previous studies, corruption is one of the significant problems and challenges faced by the international community at this time.

Corruption does not only threaten the fulfillment of basic human rights and cause a breakdown in democracy and the democratization process but also threatens the fulfillment of 
human rights, damages the environment, impedes development and increases the poverty rate of millions of people around the world. The desire of the international community to eradicate corruption to create a better, cleaner and more responsible government is very high.

The phenomenon of government people doing acts of corruption is possible because it comes from characters which are not fostered at an early age. In addition, behaviors that arise in adults are a reflection of behavioral formation in early childhood. Corruption for children is still a problem that has not been resolved until now in Indonesia. Researchers consider it necessary to research whether anti-corruption attitude through learning methods can reduce corruption rates, as well as early prevention of children aged 5-6 years or not, especially in Central Java Province as a barometer of Indonesian education.

Based on these problems, the formulated research problem is whether there is an influence of learning methods on anti-corruption attitudes of kindergarten students in Central Java province.

\section{Research methodology}

This study uses an experimental research method, in which the researchers researched with experimental class with 22 students with treatment using role-playing methods. The study was located in the Playground Qarryah Tayyibah in Karangasem sub-district, Purwokerto Selatan, Central Java province. For the control class, the researcher conducted the study in the UMP kindergarten in Kembaran sub-district with 22 students using storytelling method treatment. The sampling technique in this study using simple random sampling One-way ANOVA is the design used in this research. The constellation of the above variables can be seen in the research design as shown in Table 1 below.

Table 1. Research Design with One-Way Anova Design

\begin{tabular}{|c|c|c|c|}
\hline Group & I & II & $\sum$ \\
\hline $\mathrm{N}$ & 22 & 22 & 44 \\
\hline
\end{tabular}

The instrument of anti-corruption attitude in this study is in the form of an anti-corruption attitude observation sheet consisting of 15 items of observational statements made by the teacher in kindergarten for four months of observation. The research instrument had also been tested for validity and reliability in the field by 30 kindergarten students in Central Java province who were not included in the research sample but included in the study population, so that the anticorruption attitude instrument was declared feasible to be used in this study.

\section{Research Findings}

In general, the data description of anti-corruption attitudes is the result of the treatment carried out by the teacher in the experimental class (role-playing method) and control class (storytelling method). The following is a description of the research results:

Table 2. Description of Group Statistics of Anti-Corruption Attitude Based on Learning Methods 


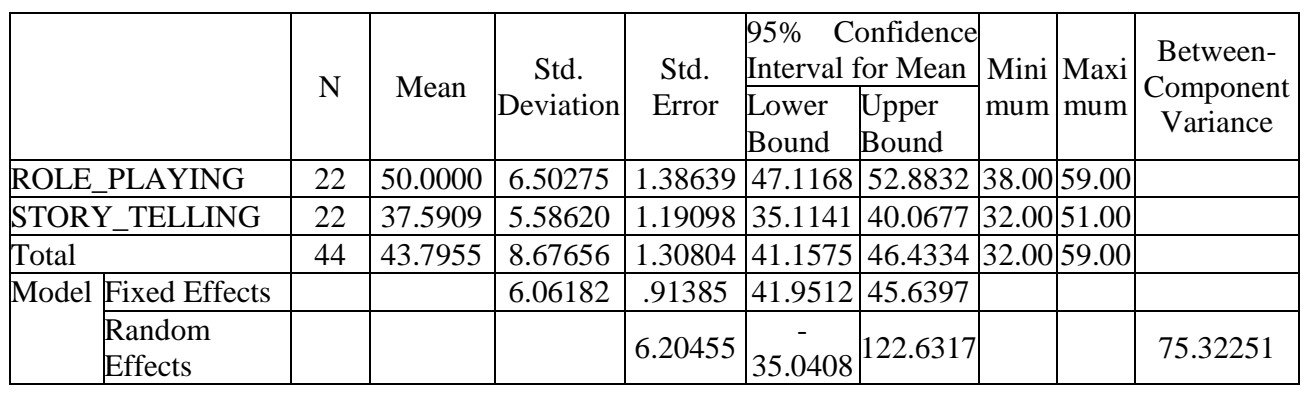

The following is a picture of the average score of the students on anti-corruption attitudes based on the learning method both by the method of role-playing and storytelling:

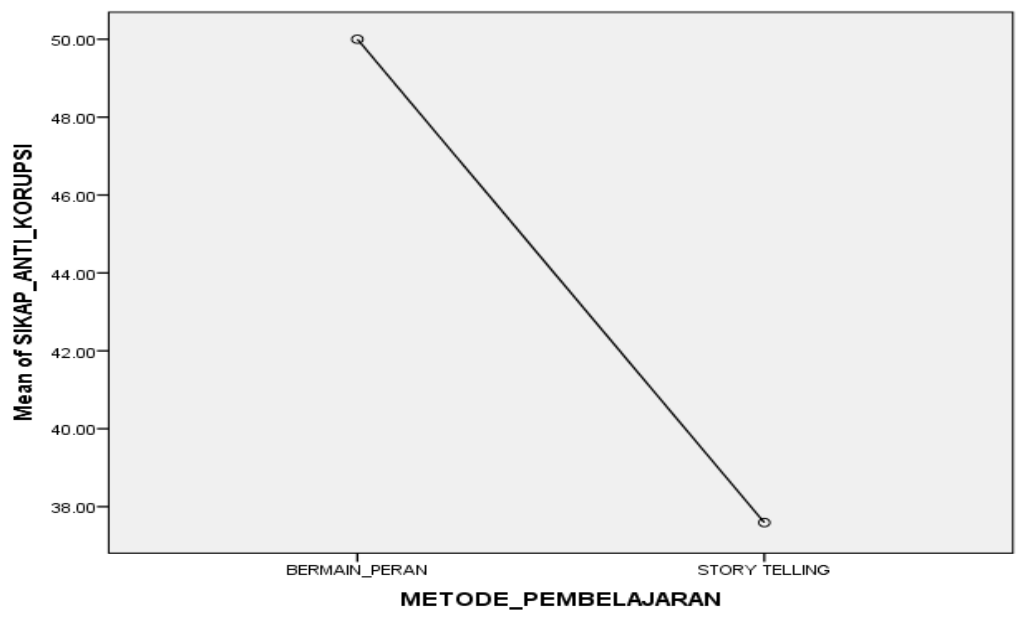

Figure 1. Mean Anti-Corruption Attitude

Based on the findings of the study using the one-way analysis of variance analysis (ANOVA), the following data are the results of the anti-corruption attitudes of kindergarten students:

Table 3. Results of analysis of variance (ANOVA) one-way

ANTI_CORRUPTION_ATTITUDE

\begin{tabular}{|l|c|c|c|c|c|}
\hline & Sum of Squares & df & Mean Square & F & Sig. \\
\hline Between Groups & 1693.841 & 1 & 1693.841 & 46.096 & .000 \\
\hline Within Groups & 1543.318 & 42 & 36.746 & & \\
\hline Total & 3237.159 & 43 & & & \\
\hline
\end{tabular}

\section{Discussion}

The results showed that there was an effect the learning method given by the teacher to the anti-corruption attitude which can be seen from the kindergarten students' attitude. This can be evidenced from the results of Fhit $(46,096)>\mathrm{F}$ tab (4.07) at a significance level of $0.005 \%$. It is also illustrated that the average score on anti-attitude corruption obtained by a kindergarten in the experimental class students (role-playing method) was 50.00 and it was 37.59 in the control class students (storytelling method) of the total maximum score of 60.00 in the instruments.

The right method can help children to understand what they want to understand. The method is the way the teacher implements the learning process by the objectives to be achieved; it is very 
important to determine the content that children learn with the right method. The application of the right method determines the mastery of content taught by the teacher.

According to Djamarah [1] the method is a method used to achieve the stated goals. According to Prawiradilaga [2] the learning method is a presentation technique chosen and applied in line with the use of media and learning resources. The role-playing method and storytelling method are two methods that tend to be different. Morrison [3] stated that roleplaying included: 1) participating in various drama activities that became longer and more complex; 2) showing increased creativity and imagination using material and in playing different roles in dramatic situations.

Research by Maria Vinogradova and Natalia Ivanova [4] in "Pedagogical conditions for Role Playing Game Development in Senior Preschool-Age Children" state that Roleplaying is very much needed in childhood at an early age; children try to play the role of someone else in the story. When this method is used in early childhood in this case to eradicate anti-corruption attitudes, it tends to succeed, because the children themselves demonstrate in a context of drama so that the child truly understands how he can carry out an attitude under the prevailing norms especially the attitude of anti-corruption. With the role-playing method, they are still eager to carry out their actions so that this has an impact on the anti-corruption attitude they show in school activities.

Research entitled [5] in a "The Effects of Using the Play Method to Enhance The Mastery of Vocabulary Among Preschool Children" found that the application of the playing method can offer huge benefits to preschoolers in the learning process. This is quite different with a storytelling method where the teacher tells the child using the book media, while the children (students) tend to be passive (only listening). In the storytelling method, children only listen to the teacher's story and tend to be silent. This makes the students cannot live the story up and cannot know how they should behave under the prevailing norms (anti-corruption attitude).

Opinion [6] attitude is defined as an evaluative concept that has been studied and associated with our patterns of thoughts, feelings, and behavior. People are not born with a certain attitude, but we will shape attitudes through the observation process, the respondent's condition, and the type of cognitive learning.

Research [7] stated that elaboration theory agrees with Bloomyang's taxonomy to think that early childhood when learning there are several processes through which an early learner must acquire new knowledge (cognitive), second through skills and thirdly indicated by attitude (effective). From the results of the research, Kumalasari [8] stated that the anti-corruption attitude is an attitude against corruption by supporting good values. Attitudes that make people feel embarrassed if they are tempted to commit corruption and they feel angry when they see it. "There are three fundamental attitudes that will make people immune to the temptations of corruption: Honesty, a sense of justice and responsibility Honest means courage to express personal beliefs, showing Ki Hajar Dewantara has warned that education for every child is expected in the future to have an anti-corruption integrity attitude, namely hard work, simple, courageous, responsible, fair, disciplined, independent, caring, and honest, such as being an honest trader, disciplined students, and responsible leaders. Through the game, children are invited to recognize the values of integrity.

Research by Kahyaoglu [9] titled "Play as Seen by Children and Pre-School Teachers in Turkey" aimed to understand the current perception of education in two children aged 3 and six years and ten kindergarten teachers. The results showed that both teachers and children had very similar perceptions when playing. The results also show age differences in perceptions of play, children aged 3-4 years need more 'play' with AASP tasks than children aged 5 to 6 years. The findings in this study indicate that the use of playing methods plays a more effective role in increasing students' anti-corruption attitudes compared to the use of storytelling methods in Central Java Province.

\section{Conclusion}


Based on data processing, data analysis, hypothesis testing and discussion of research findings, it can be concluded that there is an effect of learning methods on anti-corruption knowledge. Students taught by role-playing methods have a better/higher anti-corruption attitude than students taught by storytelling methods.

\section{References}

[1] Djamarah, Syaiful Bahri. StrategiBelajarMengajar. Jakarta: Rineka Cipta, p. 46, 94- 109 (2006).

[2] Prawiradilaga, Dewi Salma. Prinsipdesain Pembelajaran. Jakarta, Kencana, p. 66 (2007).

[3] Morrison, George S. Dasar-dasar Pendidikan Anak Usia Dini. Jakarta, PT Indeks, p.152 (2012).

[4] Maria Vinogradova, Natalia Ivanova. Pedagogical conditions for Role Playing Game Development in Senior Preschool Age Children. Procedia Social and Behavior Science 233, 297-301 (2016).

[5] Nair, Subadrah Madhawa. 'The effects of using the play method to enhance the mastery of vocabulary among preschool children' (Malaysia: Procedia-Social and Behavioral Sciences116, pp. 3976 - 3982 (2014).

[6] Davidoff, Linda L. An Introduction to Psychology. Erlangga: Jakarta PT. Gelora Aksara Pratama. p. 333 (2001).

[7] Vencie Allida, Alice. Dhliwayo et all. Assessment Of Teacher Education Curriculum In Kenya: Transforming For The Future, Baraton Interdisciplinary Research Journal, 7 (Special Issue), pp 1-9 (2017).

[8] Kumalasari, Kokom dan Didin Saripudin. Integration of Anti-Corruption Education in School's Activities, American Journal of Applied Sciences, 12 (6): 445.451 DOI: 10.3844/ajassp.2015.445.451, h.449 (2015).

[9] Kahyaoglu, Hale A. et, al. Play as seen by children and pre-school teachers in Turkey. Turkey, Procedia - Social and Behavioral Sciences 152, pp. 149-153 (2014). 